\title{
Biochemical and Histopathological Effects on Liver Profile due to Acute and Subacute Oral Toxicity of Somina on Rats
}

\author{
Aisha Azmat*, Muhammad Ahmed, \\ Umm Al-Qura University, Faculty of Medicine Department of Physiology, Makkah. Saudi Arabia.
}

Authors' Contributions

1 Conception \& Study design, Data Collection

\& Processing, Data Analysis and/or

Interpretation, Drafting of Manuscript.

2 Data Collection \& Processing, Data Analysis and/or Interpretation, Drafting of Manuscript,

Critical Review.

\section{Article info.}

Received: January 21, 2021

Accepted: May 22, 2021

Funding Source: Nil

Conflict of Interest: Nil

Cite this article: Azmat A, Ahmed $M$. Biochemical and Histopathological Effects on Liver Profile due to Acute and Subacute Oral Toxicity of Somina on Rats. RADS J Pharm Pharm Sci. 2021; 9(1):60-65.

*Address of Correspondence Author: aishaazmatkhan@hotmail.com

\begin{abstract}
A B S TRACT
Background: Limited research studies are reported regarding the toxicological effect of different herbal medicine already used in different countries.
\end{abstract}

Objective: This research study was planned to examine the changes in liver (biochemical and histological) associated with oral administration of somina (acute and sub-acute) in rats.

Methodology: Group- I served as control (saline), while other groups (II, III) were daily treated with somina at different doses of $0.285 \mathrm{~g} / \mathrm{kg}$ (group - II), $10 \mathrm{~g} / \mathrm{kg} /$ day (group - III), for 14 (set I), 21 (set II), and 30 (set III) consecutive days. Each group contains 12 rats. During the study period, signs and behavioral changes, mortality, were observed. At the end of study period, blood sample was drawn directly from heart, for the estimation of liver enzymes: Bilirubin (BIL), alkaline phosphatase (ALP), serum glutamic pyruvic transferase (SGPT), aspartate aminotransferase (SGOT), Albumin (ALB) and total protein (TP). The liver was carefully dichotomized, weighed, and further processed for histopathological analysis.

Results: Herbal drug somina was claimed to be practically non-toxic as in rats no mortality was recorded after the oral administration of somina (14, 21 and 30 consecutive days). Liver profile showed non-significant changes in treated group- II and III (P > 0.05), as compared to the control (group- I). The histopathological examination did not reveal any deteriorative effect.

Conclusion: It was concluded that oral administration of somina did not produce any significant detrimental effects on rat liver (biochemical and histopathological parameters), even at doses of $10 \mathrm{~g} / \mathrm{kg} / \mathrm{day}$ indicating its safe use.

Keywords: Biochemical, histopathological, Somina, Liver profile.

\section{INTRODUCTION}

Hamdard Laboratories (Waqf) Pakistan is producing different herbal medicines used in different ailments; one of the pronounced medicine is somina. It is composed of following medicinal plants.

Sesamum indicum: $14 \%$

Sesame seeds
Prunus amygdalus $12 \%$

Papaver somniferum 10\%

Lactuca scariola $5 \%$

Lagenaria vulgaris $12 \%$

Previous studies indicated that somina (herbal preparation) possess sedative, hypnotic, anxiolytic activities [1]. It is beneficial in insomnia and maintains 
sleep cycle [1]. In Pakistan different herbalist (Hakeem) prescribed somina, for the treatment of mental health disorders. Somina strengthen the memory processes and alertness of brain and increases memory retention power by affecting the neurotransmitters level [2]. Further, the cardiovascular activity of somina showed its hypotensive effect [3], positive inotropic and negative chronotropic effects [4]. Despite the scientific activities and significant effects of Somina, some of the single dose toxicological studies showed that somina is practically non-toxic [5], and did not produce any teratological effect [6]. However, these alternative herbal medicines have a risk of toxicity for human [7]. Previously some traditional herbal medicines were claimed to be harmful or toxic [8]. That's why this study was planned to inspect the acute and subacute toxicity of somina at different doses because all things are poisons, for there is nothing without poisonous qualities. It is only dose and frequency of dose, which makes a thing a poison. The present study was aimed to estimate the effect of somina on main target organs (liver) for its possible toxic effects after acute and subacute oral administration of somina.

\section{MATERIALS AND METHODS}

\section{Drug}

Hamdard laboratories (Waqf) Pakistan provided the herbal drug Somina for present study. It is available in powdered form. Recommended human dose is $10 \mathrm{~g}$ powder $/ 70 \mathrm{~kg}$.

$70 \mathrm{~kg} \quad 10 \mathrm{~g}$

$1 \mathrm{~kg} \quad 0.142 \mathrm{~g}$ or $142 \mathrm{mg}$

Two different doses of Somina were prepared by mixing powder in distilled water.

$285-\mathrm{mg} / \mathrm{kg}$ (2 times $>$ human dose)

$10 \mathrm{~g} / \mathrm{kg}$ (70 times > human dose)

Saline $(0.9 \% \mathrm{NaCl})$ was also used as control.

\section{Ethical Considerations}

All experimental work (animal handling) was conducted in accordance with relevant national legislation on the use of animals for research [9].

The experimental handling procedures were approved by the Animal Ethics Board of the DRHMIIPHS, Hamdard University, Karachi, Pakistan; which sanctioned the experiments according to regulations that conform to the provisions of the Declaration of Helsinki (1995).

\section{Experimental Animals}

Sprague-Dawley rats (200-225g) were randomly selected and accommodated in cages seven days before the start of experimentation for close monitoring of their body weight with free access to food and tap water ad libitum.

\section{Experimental protocol}

Following sets of experiments were conducted during present study (Table 1).

Table 1. Protocol of Study.

\begin{tabular}{|c|c|c|c|c|c|}
\hline \multirow{2}{*}{$\begin{array}{c}\text { Experimental } \\
\text { Set }\end{array}$} & \multicolumn{2}{|c|}{ Number of Rats } & \multirow{2}{*}{$\begin{array}{c}\text { Group I } \\
\text { Control } \\
\text { (0.9\% Saline) }\end{array}$} & \multirow{2}{*}{$\begin{array}{c}\text { Group II } \\
\text { Somina } \\
285 \mathrm{mg} / \mathrm{kg}\end{array}$} & \multirow{2}{*}{$\begin{array}{c}\text { Group III } \\
\text { Somina } \\
10 \mathrm{~g} / \mathrm{kg}\end{array}$} \\
\hline & Male & Female & & & \\
\hline First set & 6 & 6 & 14 days & 14 days & 14 days \\
\hline Second set & 6 & 6 & 21 days & 21 days & 21days \\
\hline Third set & 6 & 6 & 30 days & 30 days & 30 days \\
\hline
\end{tabular}

*All doses were administered daily.

All Animals were weighed daily before dosing. They were treated orally and observed in first 2 hour after dosing. At the end of study (24 hours after the last dose) thiopental $(40 \mathrm{mg} / \mathrm{kg} \quad$ i.p.) was injected intraperitoneally to rats [10] for autopsy and dissection of liver. 


\section{Biochemical studies (Liver profile)}

Before dissection, the blood samples were collected directly from heart (cardiac puncture) with sterile disposable syringe. Blood sample (approximately 3 to $4 \mathrm{ml}$ ) then centrifuged, at $3000 \mathrm{rpm}$ for $15-20 \mathrm{~min}$ and serum was separated. Different kits (Diagnostica Merck, Germany) were used for the measurement of Liver profile (TP, BIL, cholesterol, glucose, ALP, SGPT, SGOT and uric acid) on the same day [11].

\section{Histopathological studies}

For histopathological studies liver was removed immediately after the blood was collected. From each rat, a part of the lobe was sliced, processed and stained (hematoxylin and eosin). Prepared permanent slide was used for the examination of liver morphology [11].

\section{Statistical Analysis}

One way ANOVA followed by dunnett's test determined the statistical significance between the control and treated groups (II, III). Results were tabulated as average values and mean standard error (average \pm S.E).

\section{RESULTS}

Rats (male and female) were treated with Somina $(285 \mathrm{mg} / \mathrm{kg}$ and $10 \mathrm{~g} / \mathrm{kg}$ ) which is 2 and 70 times greater than human dose $(10 \mathrm{~g} / \mathrm{kg}$ powder $/ 70 \mathrm{~kg})$ for 14,21 and 30 consecutive days. Any mortality or morbidity was not observed during/after experimental period as shown in Table 2. All experimental animals were continuously monitored and did not show any sign of toxicity. Some non-significant behavioral changes were noticed in first 120 mins after dosing like grooming, sedation, decreased motor activity, corner sitting, and palpaberal ptosis. All animals were autopsied that revealed that no gross change was observed in liver. There were non-significant differences in body weight and liver weight when compared with the control group (Table 2).

Table 2. Toxicological study of somina after 14, 21 and 30 days treatment.

\begin{tabular}{|c|c|c|c|c|}
\hline DOSE & Days & Mortality & Body weight (g) & Liver weight $(\mathbf{g})$ \\
\hline \multirow{3}{*}{ Control (saline) } & 14 & $0 / 12$ & $228.05_{ \pm} 9.46$ & $7.35_{ \pm} 1.43$ \\
& 21 & $0 / 12$ & $220.40 \pm 10.24$ & $7.02 \pm 0.88$ \\
& 31 & $0 / 12$ & $221.67 \pm 6.53$ & $7.11_{ \pm} 1.52$ \\
\hline Treated & 14 & $0 / 12$ & $199.65 \pm 7.56$ & $7.23 \pm 1.29$ \\
$\mathbf{2 8 5} \mathbf{~} \mathbf{g} / \mathbf{k g}$ & 21 & $0 / 12$ & $212.96 \pm 12.10$ & $6.58_{ \pm} 1.06$ \\
& 30 & $0 / 12$ & $208.82 \pm 6.32$ & $7.54 \pm 0.14$ \\
\hline \multirow{2}{*}{ Treated } & 14 & $0 / 12$ & $215.23 \pm 8.43$ & $6.98_{ \pm} 0.17$ \\
$\mathbf{1 0} \mathbf{g} / \mathbf{k g}$ & 21 & $0 / 12$ & $218.35_{ \pm} 3.99$ & $7.41 \pm 0.43$ \\
& 30 & $0 / 12$ & $223.14 \pm 8.67$ & $7.45_{ \pm} 1.32$ \\
\hline
\end{tabular}

The values are presented as mean+S.E.

$\mathrm{n}=12$. ${ }^{*}$ Indicates the significant difference when compared with control $(\mathrm{P}<0.05)$.

\section{Effect of Somina on biochemical parameters}

The dose of Somina $(285 \mathrm{mg} / \mathrm{kg})$ had decreased the serum level of bilirubin, total protein, Glucose, SGOT and uric acid. This change in different biochemical parameters $(P>0.05)$ throughout the study period was non-significant. It increased the serum level of cholesterol and alkaline phosphatase but this increase is non-significant $(P>0.05)$ when compared with their respective control (Table 3 ). The nonsignificant data collected after 21 and 30 days were interpreted as biological variability normally observed in rats. 
Table 3. Effect of Somina on Liver Profile.

\begin{tabular}{|c|c|c|c|c|c|c|c|}
\hline Parameters & Control & \multicolumn{2}{|c|}{14 days } & \multicolumn{2}{c|}{21 days } & \multicolumn{2}{c|}{30 days } \\
\hline & & $\begin{array}{c}\text { Somina } \\
(285 \mathrm{mg} / \mathrm{kg})\end{array}$ & $\begin{array}{c}\text { Somina } \\
(10 \mathrm{~g} / \mathrm{kg})\end{array}$ & $\begin{array}{c}\text { Somina } \\
(285 \mathrm{mg} / \mathrm{kg})\end{array}$ & $\begin{array}{c}\text { Somina } \\
(10 \mathrm{~g} / \mathrm{kg})\end{array}$ & $\begin{array}{c}\text { Somina } \\
(285 \mathrm{mg} / \mathrm{kg})\end{array}$ & $\begin{array}{c}\text { Somina } \\
(10 \mathrm{~g} / \mathrm{kg})\end{array}$ \\
\hline $\begin{array}{c}\text { Total } \\
\text { Protein (TP) }\end{array}$ & $6.05+0.217$ & $5.95+0.13$ & $6.52+0.71$ & $6.28+0.14$ & $5.98_{ \pm} 1.23$ & $6.12 \pm 0.32$ & $6.89_{ \pm} 1.59$ \\
\hline $\begin{array}{c}\text { Bilirubin } \\
\text { (BIL) }\end{array}$ & $1.63+0.26$ & $1.59+0.62$ & $1.36+0.56$ & $1.71+0.56$ & $1.69_{ \pm} 0.62$ & $1.34 \pm 0.98$ & $1.56 \pm 0.64$ \\
\hline Cholesterol & $112.5+1.08$ & $108.5+1.58$ & $96.5+5.06$ & $92.5+7.36$ & $90.85 \pm 5.25$ & $92.42 \pm 7.35$ & $88.65_{ \pm} 1.26^{*}$ \\
\hline Glucose & $80.26+1.35$ & $85.62+2.30$ & $88.96+5.39$ & $80.57+3.51$ & $78.35 \pm 3.51$ & $75.32 \pm 3.56$ & $72.68_{ \pm} 3.51$ \\
\hline ALP & $219.63+28.40$ & $206.3+18.4$ & $196.3+16.4$ & $203.69+17.6$ & $222.22 \pm 26.3$ & $212.36 \pm 25.3$ & $218.63 \pm 15.6$ \\
\hline SGOT & $65.29+3.72$ & $62.36+7.32$ & $56.29+6.59$ & $64.96+1.53$ & $68.39_{ \pm} 5.27$ & $63.16 \pm 2.57$ & $59.95_{ \pm} 7.23$ \\
\hline SGPT & $30.60+2.12$ & $25.08+1.26$ & $32.86+3.16$ & $28.65+5.25$ & $29.47 \pm 5.31$ & $30.47 \pm 2.56$ & $31.16 \pm 3.56$ \\
\hline Uric acid & $3.66+0.52$ & $3.68+0.28$ & $2.98+1.25$ & $2.45+1.96$ & $3.26 \pm 0.93$ & $2.99 \pm 1.23$ & $2.56 \pm 0.92$ \\
\hline
\end{tabular}

The values are presented as mean+S.E.

$\mathrm{n}=12$. ${ }^{*}$ Indicates the significant difference when compared with control $(\mathrm{P}<0.05)$.

\section{HISTOPATHOLOGICAL EFFECT OF SOMINA ON LIVER}

The histopathological study confirmed that somina did not affect liver. Liver histological photograph (Figure 1) confirmed that any type of structural \& functional disturbance of liver did not observe after the administration of somina. Hepatocytes are flat and arranged into lobules. The sinusoids are lined by a discontinuous layer of cells. Necrotic lesions were not seen in animal treated with somina $(285 \mathrm{mg} / \mathrm{kg}$, $10 \mathrm{~g} / \mathrm{kg}$ ) and hepatocytes were comparable with the normal control (Figure 1).

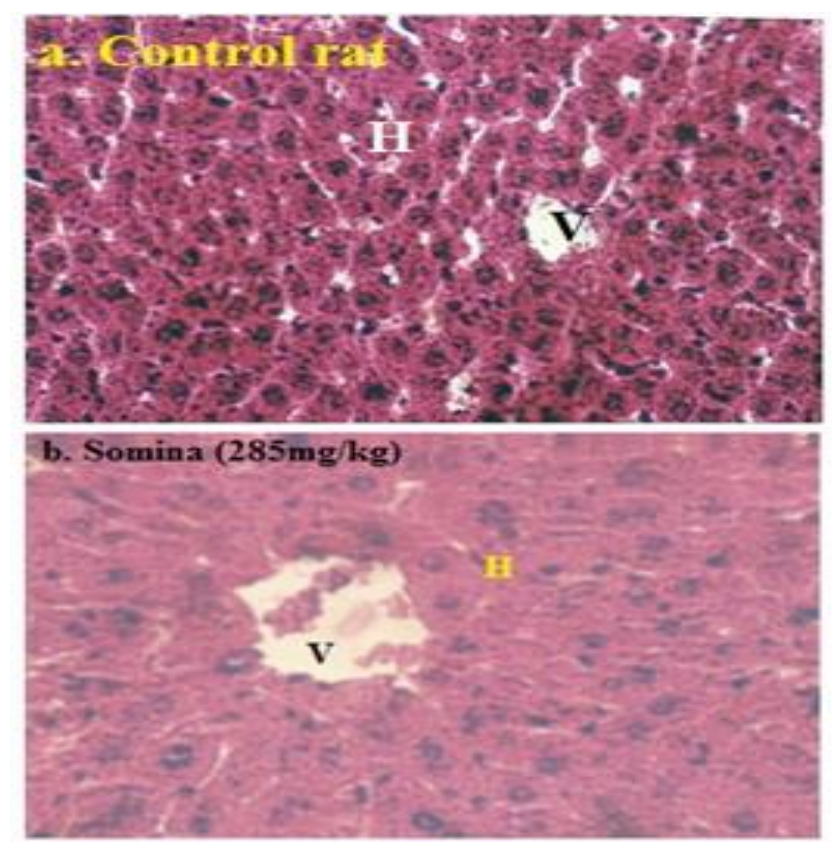

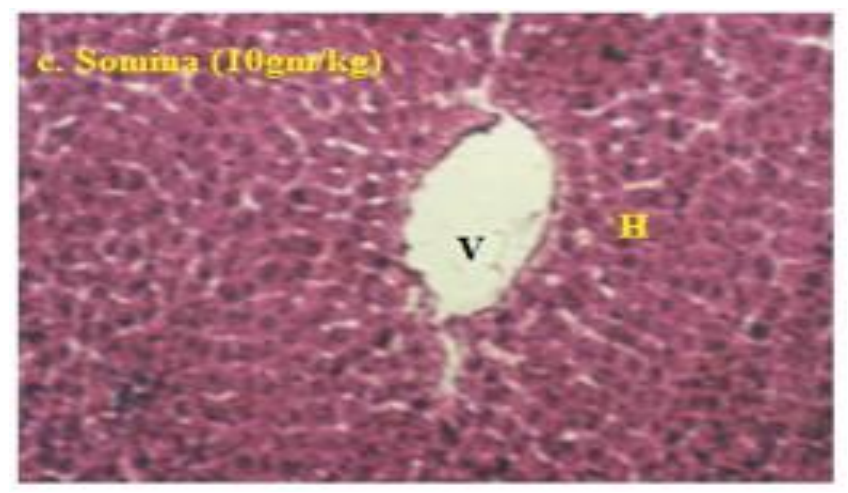

Figure 1. Histopathology of rat livers following administration of Somina $(285 \mathrm{mg} / \mathrm{kg}, 10 \mathrm{~g} / \mathrm{kg}$ : b and c respectively) compared with its control (a). $\mathrm{H}$, hepatocyte; V, central vein; Staining was done using $\mathrm{H} \& \mathrm{E}$ and magnification was $\times 400$.

\section{DISCUSSION}

There is growing research interest about the evaluation of toxic effects of alternative medicine used commercially. Although, these medicines were extracted from natural resources but contain different active constituents. The specific and explicit mechanism of action as well as adverse effects are still anonymous [12]. Different herbal medicines are reported to cause severe complication (Severe liver damage: 13), such as Sedum aizoon, Shan Chi (Gynura segetum:14), germander (Teucriumchamaedrys), chaparral (Larrea tridentate) etc [15]. Hence, biochemical and histopathological 
alterations associated with oral acute and subacute toxicity of somina (an alternative medicine used in Pakistan) was conducted.

Previously Ahmed [5] reported that $\mathrm{LD}_{50}$ value of the somina was found to be more than $10 \mathrm{~g} / \mathrm{kg}$ as toxicity sign were not noticed up to $10 \mathrm{~g} / \mathrm{kg}$ and the minimum lethal dose was more than $10 \mathrm{~g} / \mathrm{kg}$ when given orally.

Organ weights of experimental animals are important parameters for the valuation of drug-associated toxicities [16]. Hence the non-significant changes in liver weight in the current investigation even at very high dose $(10 \mathrm{~g} / \mathrm{kg}$ for 30 days) of somina indicates its nontoxic potential on liver because significant alterations in liver weight may suggest hepatocellular hypertrophy induced by treatment [17].

For further analysis liver function tests were conducted to interpret the functional state of the liver after the acute and sub-acute administration of somina. These enzyme levels described the functionality (albumin), cellular integrity (transaminases) and biliary tract (alkaline phosphatase) performance [18]. SGPT enzyme level rises during liver damage due to necrotic hepatocytes [19] present results suggest that SGPT level did not show any significant variation even after the administration of somina for 30 consecutive days which indicates the integrity of hepatocytes. The nonsignificant variation in ALP and bilirubin levels after the administration of somina (14 and 30 consecutive days) is usually a peculiar finding in non-cholestatic liver disease [20]. Non-significant variation in Total protein suggests intact liver mass function [20]. These biochemical parameters are the index of liver function, results suggest that the somina $(10 \mathrm{~g} / \mathrm{kg} / \mathrm{d})$ does not induce toxicity to the liver. These findings were further confirmed by the histological findings of the liver shown in Figures 1. Somina, when administered in high dose $(10 \mathrm{~g} / \mathrm{kg} / \mathrm{d})$ for 30 consecutive days did not produce any significant damage/deterioration in the internal integrity of Liver. Basically somina contain all natural seeds Like Lagenaria vulgaris (calabash or bottle gourd), Prunus amygdalus (Almond) and Sesamum indicum (sesamum) used at homes.

\section{CONCLUSION}

In conclusion, somina did not cause either acute or sub-chronic toxicities in rats. It is concluded that Somina is practically non-toxic herbal drug. According to Loomis [21] any drug, which is given $5-15 \mathrm{~g} / \mathrm{kg}$, did not show any mortality is practically non-toxic drug. The biochemical and histopathological examination also suggest that it did not produce any significant toxic effect.

\section{REFERENCES}

1. Azmat A, Ahmed M, Zafar N, Ahmad SI. Neuropharmacological profile of Somina (Herbal Drug) in mice and rats. Pak $\mathrm{J}$ Pharmacol. 2008;25:53-58

2. Azmat A, Ahmed M, Haider S, Haleem DJ, Zafar $\mathrm{N}$, Ahmad SI. Enhanced memory processes under the influence of herbal drug Somina and its effect on brain serotonin. Afr $J$ Pharm Pharmacol. 2012;6:2458-63.

3. Azmat A, Ahmed M. Pharmacological Evidence of Hypotensive Activity of Somina (Herbal drug) in Normotensive Rats. Trop J Pharmaceut Res. 2014;13(11):1863-1866.

4. Azmat A, Azeem MA, Zafar N, Ahmad SI. Physiological and pharmacological effect of somina (Herbal preparation) on cardiac parameters. Pak J Pharmacol. 2005;22(2):35-40.

5. Ahmed M. Acute Toxicity (Lethal Dose 50 Calculation) of Herbal Drug Somina in Rats and Mice. Pharmacol Pharmacy. 2015;6(03):185-189.

6. Ahmed M, Azmat A. Effects of unani anxiolytics (Somina) on general reproductive performance and teratology in rats. Int $\mathrm{J}$ Pharm Pharm Sci. 2017;9(3):30-34.

7. Palmer ME, Haller C, McKinney PE, KleinSchwartz W, Tschirgi A, Smolinske SC, et al. Adverse events associated with dietary supplements: an observational study. Lancet. 2003;361:101-6.

8. Garba SH, Jacks TW, Onyeyili PA, Nggada HA. Embryofetal effects of the methanolic root extract of Cissampelos MucronataA. rich in rats. J Anamt. 2014;3:286-93.

9. Home Office. Animals [Scientific Procedures] Act 1986. Code of Practice for the Housing and Care of Animals Used in Scientific Procedures. Available online: http://www.officialdocuments.gov.uk/document/hc8889/hc01/0107/0 107.pdf.

10. Ulicna O, Greksak M, Vancova O, Zlato L, Galbavy PBO, Nakano M. Hepatoprotective Effect of Rooibos Tea (Aspalathus linearis) on CCl4Induced Liver Damage in Rats. Physiol Res. 2003;52:461-466.

11. Kouame K, Peter Al, Akang EN, Moodley R , Naidu EC , Azu OO. Histological and biochemical effects of Cinnamomum cassia nanoparticles in 
kidneys of diabetic Sprague-Dawley rats. Bosn J Basic Med Sci. 2019;19(2):138-145.

12. Elvin-Lewis M. Should we be concerned about herbal remedies. J Ethnopharma. 2001;75:141-64.

13. Amadi CN, Orisakwe OE. Herb-Induced Liver Injuries in Developing Nations: An Update. Toxics.2018;6(2):24.

14. Lin G, Wang JY, Li N, Li M, Gao H, Ji Y, Zhang F, Wang $\mathrm{H}$, Zhou $\mathrm{Y}$, Ye $\mathrm{Y}$, et al. Hepatic sinusoidal obstruction syndrome associated with consumption of Gynura segetum. J. Hepatol. 2011;54:666-673.

15. Stickel F, Egerer G, Seitz HK. Hepatotoxicity of Botonicals. Pub Health Nutr. 2000;3:113-24.

16. UNL Environmental Health and Safety Toxicology and exposure guidelines. [Last revised on 2003]; 2002 402:472-925. Available from: http://ehs.unl.edu .

17. Greaves P. Histopathology of Preclinical Toxicity Studies: Interpretation and Relevance in Drug
Safety Evaluation. 3rd ed. Amsterdam: Elsevier Science; 2007. 466-7.

18. Agbaje EO, Adeneye AA, Daramola AO. Biochemical and toxicological studies of aqueous extract of Syzigiumaromaticum (L.) Merr. and Perry (Myrtaceae) in rodents. Afr J Tradit Compl Altern Med. 2009;6:214-54.

19. Ozer J, Ratner M, Shaw M, Bailey W, Schomaker S. The current state of serum biomarkers of hepatotoxicity. Toxicol. 2008;245:194-205.

20. Giannini EG, Testa R, Savarino V. Liver enzyme alteration: a guide for clinicians. CMAJ. 2005;172(3):367-379.

21. Loomis TA., 1978, Essentials of Toxicology, 3rd Ed. Lea \& Febiger, Philadelphia, PA.1-12. 